\title{
Pengembangan Urban Farming Berdasarkan Preferensi Masyarakat Kecamatan Semampir Kota Surabaya
}

\author{
Nadia Belinda dan Dian Rahmawati \\ Departemen Perencanaan Wilayah dan Kota, Fakultas Teknik Sipil dan Perencanaan, Institut Teknologi \\ Sepuluh Nopember (ITS) \\ e-mail:d_rahmawati@urplan.its.ac.id
}

\begin{abstract}
Abstrak-Urban farming bertujuan untuk memperkuat ketahanan pangan suatu kawasan dan memiliki multiplier effect on economy. Urban farming bermula di Amerika Serikat sebagai upaya terhadap buruknya situasi dan kondisi ekonomi beberapa negara pada saat perang dunia II. Di Surabaya, urban farming dilakukan guna mengentaskan masalah ekonomi dan ketahanan pangan untuk gakin. Namun pada faktanya di Kecamatan Semampir, kegiatan urban farming belum berkembang akibat belum optimalnya peran masyarakat dan kelembagaan setempat selaku pengelola utama. Untuk itu diperlukan pengembangan urban farming berdasarkan preferensi masyarakat agar peran masyarakat menjadi optimal. Sasaran pertama dari penelitian ini adalah identifikasi potensi dan permalasahan Kecamatan Semampir untuk kegiatan urban farming menggunakan teknik teoritikal deskriptif. Sasaran kedua adalah mengidentifikasi preferensi masyarakat Kecamatan Semampir mengenai urban farming menggunakan confirmatory factor analysis (CFA). Sasaran ketiga adalah merumuskan pengembangan urban farming berdasarkan preferensi masyarakat Kecamatan Semampir menggunkan teknik analisis deskriptif kualitatif. Hasil akhir dari penelitian ini berupa arahan pengembangan urban farming berdasarkan preferensi masyarakat Kecamatan Semampir yaitu dikembangkan di lahan private dan lahan bersama. Pada lahan private sebagai fungsi ekonomi dan ketahanan pangan dengan jenis tanaman pangan (sayuran dan protein nabati). Pada lahan bersama sebagai fungsi ruang terbuka hijau dengan jenis tanaman herbal menggunakan teknik hidroponik.
\end{abstract}

Kata Kunci-Urban farming, Semampir, Preferensi masyarakat

\section{PENDAHULUAN}

$\mathrm{U}$ RBAN FARMING merupakan suatu gerakan yang dimulai di Amerika Serikat sebagai upaya terhadap buruknya situasi dan kondisi ekonomi beberapa negara pada saat perang dunia terutama tingginya harga sayuran pada kala itu. Sekitar 20 juta victory garden dibuat selama perang dunia kedua. Victory garden berupa kegiatan membangun taman di sela-sela ruang yang tersisa. Hasil dari program tersebut membuat pemerintah Amerika Serikat mampu menyediakan 40\% kebutuhan pangan warganya pada waktu itu. [1] Di Kota Surabaya, pertanian kota sudah dilakukan oleh masyarakat secara marginal. Menurut penelitian dari Setiawan (2002), urban farming di Surabaya dilakukan antara lain disekitar peran sektor pertanian dalam struktur ekonomi kota Surabaya relatif kecil dan cenderung menurun setiap tahunnya. Terhitung mulai tahun 2007 mencapai $0,11 \%$, tahun 2008 mencapai $0,10 \%$, tahun 2009 mencapai $0,10 \%$, tahun 2010 mencapai 0,09 \%, dan pada tahun 2011 mencapai $0,08 \%$. Penurunan ini bisa dimaklumi karena kota Surabaya lebih dikenal sebagai kota perdagangan dan jasa. [2]. Berdasarkan musyawarah Perencanaan Pembangunan Kota Surabaya tahun 2009 oleh Pemerintah Kota Surabaya dan mengacu pada RPJMD Kota Surabaya diketahui bahwasannya dalam penambahan strategi ruang terbuka hijau, jenis ruang terbuka hijau berupa urban farming direncanakan akan di bangun seluas 26,35 Ha. [3]. Urban Farming diadakan dalam rangka penanggulangan kemiskinan di kalangan keluarga miskin (Gakin) di Kota Surabaya sekaligus juga upaya untuk memenuhi kebutuhan mereka dibidang pangan.

Daerah Utara Surabaya merupakan daerah dengan basis perdagangan dan jasa serta permukiman. Kecamatan Semampir merupakan salah satu kecamatan yang berada di daerah utara Surabaya dengan kondisi sebagai wilayah termiskin se-Surabya berdasarkan parameter papan, pangan, dan pekerjaan. Dimana $50 \%$ dari kasus gizi buruk di Surabaya terjadi pada Kecamatan Semampir dan telah digolongkan pada tingkat rawan balita gizi kurang yakni terdapat pada rentan $>1,25-1,50$. [4]. Kecamatan Semampir juga dijadikan sebagai parameter wilayah termiskin se-Surabaya, hal ini terlihat bahwa jumlah kk yang tergolong pra sejahtera II sebanyak $55 \mathrm{kk}$ yang mana lebih dari $50 \mathrm{kk}$, sehingga dapat digolongkan sebagai wilayah miskin. [5]. Kecamatan Semampir juga merupakan kecamatan yang memiliki kepadatan penduduk tinggi dimana dalam rentang $>250$ jiwa/Ha, Kepadatan penduduk di Kecamatan Semampir mencapai 259 jiwa/Ha. [4]. Dikarenakan tingginya kepadatan penduduk tersebut, Kecamatan Semampir tidak memiliki Ruang Terbuka Hijau yang cukup. [5].

Urban farming merupakan salah satu solusi alternatif yang mudah penerapannya untuk dapat meminimalisir gejala-gejala yang terjadi di Kecamatan Semampir dalam skala rumah tangga. Di Kecamatan Semampir pada saat ini telah terdapat beberapa kegiatan urban farming, akan tetapi kegiatan urban farming tersebut belum sepenuhnya merata dilakukan oleh semua warga dan belum optimal. Hal ini dikarenakan kurangnya partisipasi masyarakat setempat akan gerakan urban farming ini. Sehingga preferensi masyarakat akan urban farming merupakan hal yang penting dalam merumuskan urban farming di Kecamatan Semampir. Oleh sebab itu perlu diketahui preferensi masyarakat apa yang berpengaruh 
terhadap perumusan arahan urban farming di Kecamatan Semampir Surabaya.

\section{METODE PENELITIAN}

\section{A. Jenis dan Pendekatan Penelitian}

Pendekatan yang digunakan dalam penelitian ini adalah pendekatan rasionalistik. Jenis penelitian dalam penelitian ini adalah eksploratif dan deskriptif.

\section{B. Variabel Penelitian}

Variabel penelitian yang digunakan untuk mengidentifikasi preferensi masyarakat yang berpengaruh terhadap perumusan arahan urban farming di Kecamatan Semampir Surabaya antara lain aspek komponen urban farming (distribusi), lokasi urban farming (lahan private, lahan bersama, lahan terlantar), karakteristik urban farming di Indonesia (fungsi, sarana prasaran, jenis tanaman, kelembagaan, teknik urban farming), komponen ketahanan pangan perkotaan (tingkat ekonomi, tingkat kepadatan penduduk, status gizi), faktor yang mempengaruhi partisipasi dan preferensi masyarakat(karakteristik penduduk).

C. Mengidentifikasi Potensi dan Permasalahan Kecamatan Semampir untuk Kegiatan Urban Farming

Analisis teoritikal deskriptif [6] digunakan untuk mengidentifikasi potensi dan permasalahan di Kecamatan Semampir untuk kegiatan urban farming. Pada tahap ini, akan dilakukan deliniasi wilayah studi berdasarkan aspek komponen ketahanan pangan perkotaan agar arahan pengembangan urban farming tepat sasaran. Pada analisis ini akan dilakukan komparasi antara kriteria urban farming dengan hasil observasi menggunakan jotted notes pada perwakilan warga di kelurahan terpilih. Hasil dari analisis ini akan didapatkan peta gambaran potensi dan permasalahan untuk kegiatan urban farming.

\section{Mengidentifikasi preferensi masyarakat Kecamatan} Semampir mengenai Urban Farming

Dalam analisis identifikasi preferensi masyarakat Kecamatan Semampir mengenai urban farming menggunakan confirmatory factor analysis. Confirmatory Factor Analysis digunakan untuk mengidentifikasi faktor-faktor yang berpengaruh terhadap preferensi masyarakat Kecamatan Semampir mengenai urban farming. Analisis Faktor Eksplanatori menggunakan bantuan SPSS 20.0 dengan tahapan-tahapan dalam analisis Faktor Eksplanatori adalah :

1. Pengelompokan variabel berdasarkan faktor yang sesuai dengan tinjauan pustaka.

2. Melakukan analisis setiap faktor dengan menggunakan bantuan oftware SPSS, jika variabel yang dianalisis memiliki nilai KMO (Kaiser Meyer Olkin Measure) > 0,5 maka faktor tersebut valid sedangkan jika nilai variabel yang dianalisis memiliki nilai KMO (Kaiser Meyer Olkin Measure) $<0,5$ maka faktor tersebut tidak valid.

\section{E. Merumuskan Arahan Urban Farming Berdasarkan Preferensi Masyarakat Kecamatan Semampir}

Dalam perumusan arahan pengembangan urban farming berdasarkan preferensi masyarakat Kecamatan Semampir menggunakan analisis deskriptif kualitatif berbentuk narasi.
Dalam melakukan metode analisis ini dilakukan dengan cara mengkomparasikan antara hasil analisis pada sasaran I dan sasaran II.

\section{HASIL DAN DISKUSI}

\section{A. Identifikasi Potensi dan Permasalahan di Kecamatan} Semampir untuk Kegiatan Urban Farming.

Sebelum tahapan analisis, terlebih dahulu melakukan deliniasi wilayah studi berdasarkan parameter ketahanan pangan perkotaan, dengan hasil sebagai berikut:

Tabel 1.

Deliniasi Wilayah Studi

\begin{tabular}{|c|c|c|c|c|c|}
\hline & Ampel & "Sidotopo & Pegirian & Wonokusumo & Ujung \\
\hline $\begin{array}{c}\text { Tingkat } \\
\text { kepadatan } \\
\text { penduduk } \\
\left(\mathrm{jiw} / \mathrm{km}^{2} \text { ) }\right.\end{array}$ & 57.661 & 11.633 & 79.710 & 79.918 & 18.688 \\
\hline $\begin{array}{c}\text { Jumlah } \\
\text { kasus gizi } \\
\text { buruk } \\
\text { (jiwa) }\end{array}$ & - & - & 4 & 10 & - \\
\hline $\begin{array}{c}\text { Jumlah } \\
\text { keluarga } \\
\text { pra } \\
\text { sejahtera } \\
\text { (jiwa) }\end{array}$ & 56 & 349 & 437 & 452 & 379 \\
\hline
\end{tabular}

Setelah dilakukan deliniasi wilayah maka dilanjutkan dengan observasi dan wawancara terkait potensi dan permasalahan urban farming dengan perwakilan warga pada Kelurahan Wonokusumo dan Kelurahan Pegirian, dimana hasil dari observasi teersebut akan dikomparasi dengan standar dari pengadaan urban farming, dengan hasil sebagai berikut:

a. Lokasi

- Kelurahan Wonokusumo tidak ada lahan terlantar ataupun lahan private yang cukup luas (rata-rata rumah di Kelurahan Wonokusumo KDB 80\%-100\%), namun memiliki luasan dinding dan atap rumah yang mampu menampung minimal 1 pot, sehingga pengembang urban farming yang cocok dengan teknik vertikultur atau rooftop garden.

- Kelurahan Pegirian memiliki beberapa titik lahan terlantar serta beberapa rumah memiliki KDB 60\%, meski demikian umumnya KDB rumah di Kelurahan juga $80 \%-100 \%$. Sehingga pengembang urban farming yang cocok dengan teknik konvensional atau hidroponik untuk ukuran rumah dengan KDB 60\%-80\% dan teknik vertikultur atau rooftop garden untuk ukuran rumah KDB $>80 \%$

b. Sarana dan prasarana

- Kelurahan Wonokusumo dan Kelurahan Pegirian memiliki kondisi jaringan air bersih serta listrik yang baik/memadai dan keperluan bercocok tanam juga bisa didapatkan dengan mudah (dapat dibeli dari pasar setempat)

c. Jenis tanaman dan fungsi urban farming

- Jenis tanaman di Kelurahan Wonokusumo yang cocok dengan pengembangan urban farming teknik vertikultur/rooftop garden akan diarahkan pada jenis 
tanaman dengan tumbuh tegak tanaman yang ringan seperti bayam, kangung, kucai, sawi, dan sayuran daun lainnya. Untuk tanaman herbal seperti daun mint, ketumbar, dan kemangi.

- Jenis tanaman di Kelurahan Pegirian yang cocok dengan pengembangan urban farming teknik konvensional/hidroponik akan diarahkan pada jenis tanaman dengan tumbuh tegak tanaman yang berat seperti cabai, pare, tomat, terong, dll. Dikarenakan lahan yang lebih luas dan ada beberapa tanah kosong di Kelurahan Pegirian, bisa menanam berbagai jenis tanaman herbal dan tanaman hias.

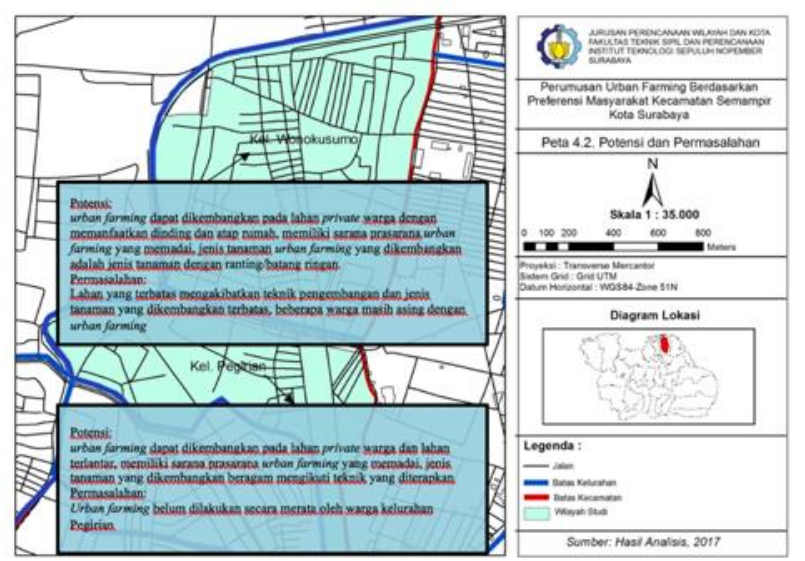

Gambar 1. Peta Potensi dan Permalasahan Kelurahan Wonokusumo dan Kelurahan Pegirian terkait urban farming.

\section{B. Identifikasi Preferensi Masyarakat di Kecamatan Semampir Mengenai Urban Farming}

Berdasarkan tabel 1, diketahui bahwa wilayah studi terpilih adalah Kelurahan Wonokusumo dan Kelurahan Pegirian, dengan demikian hal ini berpengaruh pada responden untuk sasaran II. Adapun perhitungan jumlah responden berdasarkan deliniasi wilayah sebagai berikut:

Tabel 2.

Distribusi Unit Sampel Penelitian Sesuai Deliniasi Wilayah

\begin{tabular}{cccc}
\hline Kelurahan & $\begin{array}{c}\text { Unit } \\
\text { Populasi } \\
\text { (Jiwa) }\end{array}$ & $s=\frac{n}{N} \times s$ & $\begin{array}{c}\text { Sampel } \\
\text { (jiwa) }\end{array}$ \\
\hline Wonokusumo & 60.738 & $(60.738 / 92.622) \times 30$ & 20 \\
Pegirian & 31.884 & $(31.884 / 92.622) \times 30$ & 10 \\
Total & $\mathbf{9 2 . 6 2 2}$ & & $\mathbf{3 0}$ \\
\hline \hline
\end{tabular}

Sumber: Hasil Analisis, 2017

Selanjutnya dilakukan teknik analisis confirmatory factor analysis yang akan mengkonfirmasi faktor-faktor kepada masyarakat dengan tujuan mereduksi faktor yang tidak berpengaruh dalam preferensi masyarakat Kecamatan Semampir, dalam hal ini Kelurahan Wonokusumo dan Kelurahan Pegirian, mengenai urban farming, berikut hasilnya:

a. Aspek fungsi urban farming

\begin{tabular}{ll}
\hline \hline & \multicolumn{1}{c}{ Iterasi 1 } \\
\hline KMO & 0,512 \\
Sig & 0,027 \\
MSA $<0,5$ & Tidak ada \\
\hline \hline
\end{tabular}

b. Aspek lokasi urban farming

\begin{tabular}{lll}
\hline \hline & \multicolumn{1}{c}{ Iterasi 1 } & \multicolumn{1}{c}{ Iterasi 2 } \\
\hline KMO & 0,493 & 0,5 \\
Sig & 0,042 & 0,004 \\
MSA $<0,5$ & B3 & Tidak ada \\
\hline \hline
\end{tabular}

c. Aspek jenis tanaman urban farming

\begin{tabular}{lll}
\hline \hline & \multicolumn{1}{c}{ Iterasi 1 } & \multicolumn{1}{c}{ Iterasi 2 } \\
\hline KMO & 0,5 & 0,5 \\
Sig & 0,004 & 0,000 \\
MSA $<0,5$ & $\mathrm{C} 3$ & Tidak ada \\
\hline \hline
\end{tabular}

d. Aspek teknik urban farming

\begin{tabular}{llll}
\hline \hline & \multicolumn{1}{c}{ Iterasi 1 } & Iterasi 2 & \multicolumn{1}{c}{ Iterasi 3 } \\
\hline KMO & 0,391 & 0,480 & 0,5 \\
Sig & 0,027 & 0,032 & 0,05 \\
MSA $<0,5$ & D2 & D4 & Tidak ada \\
\hline \hline
\end{tabular}

Faktor fungsi urban farming yang berpengaruh atau sesuai dengan preferensi masyarakat Kecamatan Semampir adalah urban farming sebagai fungsi ekonomi (hasil urban farming di jual), fungsi ketahanan pangan (hasil urban farming dikonsumsi pribadi), dan fungsi ruang terbuka hijau. Pada faktor lokasi urban farming, berdasarkan hasil CFA dapat diketahui bahwa masyarakat Kecamatan Semampir lebih menginginkan urban farming dikelola di lahan private dan lahan bersama. Untuk faktor jenis tanaman yang berpengaruh atau sesuai dengan preferensi masyarakata Kecamatan Semampir adalah jenis tanaman pangan (sayuran dan protein nabati) dan jenis tanaman herbal. Teknik hidroponik dan teknik vertikultur merupakan variabel yang berpengaruh atau sesuai dengan preferensi masyarakat Kecamatan Semampir pada faktor teknik urban farming.

C. Arahan Pengembangan Urban Farming yang Sesuai dengan Preferensi Masyarakat Kecamatan Semampir

Arahan pengembangan desa tertinggal kabupaten Bondowoso menggunakan analisis deskriptif berbentuk narasi. Hasil narasi diambil dari sasaran kedua penelitian. Dari hasil penelitian didapatkan bahwa:

a. Lokasi dan teknik urban farming

Pada Kelurahan Wonokusumo pengembangan urban farming dilakukan pada lahan private miliki masing masing warga dengan menerapkan teknik vertikultur.

Pada Kelurahan Pegirian, pengembangan urban farming dilakukan pada lahan private dan lahan terlantar, dimana lahan terlantar akan dikembangkan menjadi community garden. Pada lahan private dengan KDB 60\%-80\% menerapkan teknik hidroponik, dan rumah dengan KDB $>80 \%$ menerapkan teknik vertikultur. Untuk pada lahan terlantar akan diterapkan teknik vertikultur.

b. Fungsi dan jenis tanaman urban farmin

Pada Kelurahan Wonokusumo fungsi urban farming lebih diarahkan sebagai pemenuhan kebutuhan pangan, dan penunjang ekonomi dalam skala mikro. Mengingat menggunakan teknik vertikultur maka yang dikembangkan adalah jenis tanaman pangan seperti bayam, kangkung, dan sayuran daun lainnya.

Pada Kelurahan Pegirian maupun fungsi urban farming lebih diarahkan sebagai pemenuhan kebutuhan pangan, 
penunjang ekonomi, dan pemenuhan RTH dalam skala mikro. Dimana pada lahan private yang menggunakan teknik vertikultur akan mengembangkan jenis tanaman sayuran daun, dan untuk yang hidroponik akan mengembangkan cabai, pare, tomat, terong, dan lain-lain. Untuk pada lahan terlantar akan dikembangkan tanaman herbal diantaranya daun mint, ketumbar, dan berbagai macam bumbu dapur.

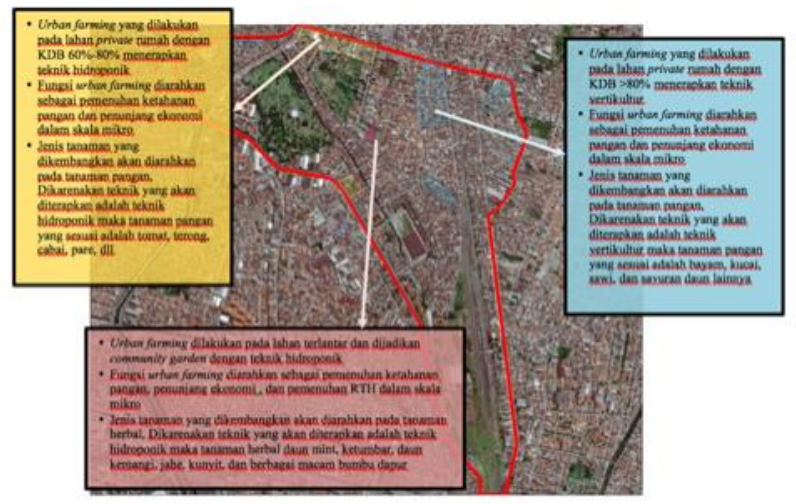

Gambar 2. Arahan Pengembangan urban farming di Kelurahan Pegirian.

\section{KESIMPULAN}

Pada penelitian ini bertujuan untuk merumuskan arahan pengembangan urban farming yang sesuai dengan preferensi masyarakat Kecamatan Semampir Kota Surabaya. Berikut ini merupakan hasil yang diperoleh dari penelitian ini :

1. Urban farming yang sesuai dengan preferensi masyarakat Kecamatan Semampir dikelola atau dikembangkan berdasarkan lokasi atau lahan yaitu lahan private dan lahan bersama. Dengan ketentuan berikut:

- Pada lahan private jenis tanaman yang dikelola adalah tanaman pangan (sayuran dan protein nabati). teknik vertikultur, maka jenis tanaman pangannya adalah bayam, kangung, kucai, sawi, dan sayuran daun lainnya. Pada lahan private yang menggunakan teknik hidroponik maka jenis tanaman pangannya adalah cabai, pare, tomat, terong dan lain-lain. Fungsi tanaman urban farming yang dikelola pada lahan private sebagai fungsi ekonomi dan fungsi ketahanan pangan. Teknik urban farming yang diterapkan dalam mengelola tanaman di lahan private adalah teknik vertikultur.

- Pada lahan bersama jenis tanaman yang dikelola adalah tanaman herbal. Fungsi tanaman urban farming yang dikelola pada lahan private sebagai fungsi ruang terbuka hijau Teknik urban farming yang diterapkan dalam mengelola tanaman di lahan bersama adalah teknik hidroponik. Dengan jenis tanaman herbal diantaranya adalah daun mint, ketumbar, daun kemangi, jahe, kunyit, dan berbagai macam bumbu-bumbu dapur.

2. Pada Kelurahan Wonokusumo akan diarahkan untuk pengembangan pada lahan private danpada Kelurahan Pegirian pada lahan private dan lahan terlantar.

3. Berdasarkan hasil penelitian, saat ini urban farming khususnya dalam skala mikro belum secara langsung dan signifikan mengatasi permasalahan utama perkotaan seperti pengentasan kemiskinan, gizi buruk, rawan pangan, dan pemenuhan ruang terbuka hijau di Kelurahan Wonokusumo dan Kelurahan Pegirian, akan tetapi urban farming merupakan solusi alternatif yang mudah untuk dilakukan warga setempat untuk meminimalisir gejala-gejala tersebut

\section{DAFTAR PUSTAKA}

[1] Beritalingkungan, "Urban Farming Sebuah Gaya Hidup," 2012. [Online]. Available: http://www.beritalingkungan.com/2012/02/urban-farming-sebuah-g aya-hidup.html.

[2] B. P. S. K. Surabaya, Kota Surabaya dalam Angka 2011. Surabaya: Badan Pusat Statistik, 2012.

[3] "pusdakota.or.id.” [Online]. Available: pusdakota.or.id.

[4] B. P. S. K. Surabaya, Kecamatan Semampir dalam Angka 2012. Surabaya: Badan Pusat Statistik, 2013.

[5] R. Normanda, "Identifikasi Faktor Penyebab Kemiskinan Kota di Kecamatan Semampir Surabaya," J. Tek. POMITS, vol. 2, 2013.

[6] P. Rahmawati, Supriharjo, Setiawan, "Community Participation in Heritage Tourism For Gresik Resilience," Procedia-Social Behav. Sci., vol. 135, pp. 142-146, 2014. 